Spare Time in Texas 
Number Twenty-one

JACK AND DORIS SMOTHERS SERIES IN TEXAS HISTORY, LIFE, AND CULTURE 


\section{Spare Time in Texas}

RECREATION AND HISTORY IN THE LONE STAR STATE

By David G. McComb 
PUBLICATION OF THIS WORK WAS MADE

POSSIBLE IN PART BY SUPPORT FROM THE

J. E. SMOTHERS, SR., MEMORIAL FOUNDATION

AND THE NATIONAL ENDOWMENT FOR THE

HUMANITIES.

Copyright (C) 2008 by the University of Texas Press

All rights reserved

Printed in the United States of America

First edition, 2008

Requests for permission to reproduce material from this work should be sent to:

Permissions

University of Texas Press

P.O. Box 7819

Austin, TX 78713-7819

www.utexas.edu/utpress/about/bpermission.html

@ The paper used in this book meets the minimum requirements of ANSI/NISO Z39.48-I992 (RI997) (Permanence of Paper).

LIBRARY OF CONGRESS CATALOGING-IN-PUBLICATION DATA

McComb, David G.

Spare Time in Texas : Recreation and history in the Lone Star State / by David G. McComb.

p. $\quad \mathrm{cm}$. - (Jack and Doris Smothers series in Texas

history, life, and culture ; 2I)

Includes bibliographical references and index.

ISBN 978-0-292-71870-8 (cl. : alk. paper)

ISBN 978-0-292-71889-o (pbk. : alk. paper)

I. Recreation-Texas-History. 2. Leisure-Texas-History.

I. Title. II. Series

GV54.T59M 332008

$790.09764-\mathrm{dc2} 2$ 
To Mary Alice 
THIS PAGE INTENTIONALLY LEFT BLANK 